\title{
Personal Laws and the Rights of Women
}

\author{
P Lakshmi*
}

Abstract

There exist different personal laws in India. The Hindus, Buddhists, Jains and Sikhs are governed by Hindu law. Muslim law applies to Muslims. The Christians are governed by Christian law and Parsi law applies to the Parsi. Jews have their own personal law. Women's rights in relation to marriage and property are not adequately protected under these personal laws. This has resulted in gross violation of human rights of women guaranteed under the Indian Constitution and also under the International Conventions relating to protection of human rights. This paper makes an examination of the provisions of different personal laws which are discriminatory against women. It recommends the unification of personal laws in the form of a uniform civil code consisting of fair, just and non-discriminatory provisions. The formulation of a uniform civil code would go a long way in improving the status of women in India.

Keywords: Constitutional Provisions, Human Rights, International Instruments, Personal Law, Position of Women

\section{Introduction}

Human rights are the rights of every individual or the rights of every human being. They are the rights which every human being must have by virtue of him or her being a human being. The Protection of Human Rights Act, 1993, defines 'human rights' as

\footnotetext{
* Assistant Professor of Law, ITM Law School, ITM University, Gurgaon, Haryana.
} 
right relating to life, liberty, equality and dignity of the individual. ${ }^{\dagger}$ They are conceived of as rights inherent in individuals as rational, free-willing creatures, not conferred by mere positive law, and not capable of being abridged or abrogated by positive law. $\ddagger$ Though the origin of human rights has a long history, the first positive manifestation of the assertion of human rights was evident on 10th December, 1948 when the United Nations Organization adopted the Universal Declaration of the Rights of Man.

\section{Measures Taken by the International Community for Protection of the Human Rights of Women}

The international community has shown its concern for the human rights of women in a number of meetings and conferences. The Convention on the Elimination of All Forms of Discrimination Against Women (CEDAW), adopted in 1979 by the UN General Assembly, is described as an international bill of rights for women. It forbids all forms of discrimination on grounds of gender as violative of fundamental freedoms and human rights. The Government of India acceded to Convention for Elimination of All Forms of Discrimination against Women 1979 and reiterated that discrimination against women violates the principles of equality of rights and respect for human dignity of equality. The Convention defines what amounts to 'discrimination against women' $\$$ and also declares that the states should take appropriate measure to eliminate it."* The Universal Declaration of Human Rights also makes explicit reference to equal protection of rights of men and women in its Preamble.

† Protection of Human Rights Act, 1993, § 2(d) (stating that "human rights" means the rights relating to life, liberty, equality and dignity of the individual guaranteed by the Constitution or embodied in the International Covenants and enforceable by courts in India).

‡ A.N. Sen, Human Rights 6 (2002).

$\S$ Convention on the Elimination of All Forms of Discrimination Against Women, Dec. 18, 1979, 1249 U.N.T.S. 13; 19 I.L.M. 33 (1980), art. 1.

${ }^{* *}$ Id. art. 13. 
The framers of the Constitution of India were much inspired by the Universal Declaration of Human Rights. This is evident from the fact that they have incorporated the same spirit in the Preamble of our Constitutiontt itself. Not only the Preamble, but, other provisions of the Constitution also seek to protect human rights. Mention may be made of right to life, which is recognized as a

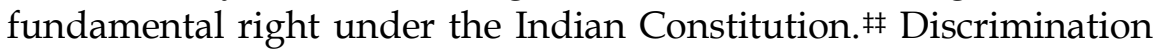
among citizens on the grounds of religion, race, caste or sex is also prohibited under the Constitution. $\$ \$$ Equal opportunity to all in matters of public employment is also granted. ${ }^{* * *}$ The Constitution guarantees to all persons equality before law and equal protection of law. ${ }^{t+t}$ Although the Constitution guarantees equal protection of rights of men and women, the discrimination against women continues and one of the important areas where this discrimination is evident is Personal Law. The various personal laws in force in country deny equality to women. The object of this paper is to examine those provisions of law which are discriminatory against women and which results in the gross violation of their human rights guaranteed under the Indian constitution and also under international conventions.

\section{Discrimination Against Women under Personal Laws}

In India an array of personal laws exist. Generally, the applicability of these laws is based on the religion professed by different communities. The Hindus, Buddhists, Jains and Sikhs are governed by Hindu law. 执 Muslim law applies to Muslims. $\$ \$ \S$ The Christians are governed by Christian law and Parsi law applies to the Parsi.

t† THE Constitution Of India, Preamble.

㧊 THE CONSTITUTION OF INDIA, art. 21.

\$ THE CONSTITUTION OF INDIA, art. 15(1).

${ }^{* * * *}$ THE CONSTITUTION OF INDIA, art. 16(1), 16(2).

ttt THE CONSTITUTION OF INDIA, art. 14.

执 The Hindu Marriage Act, 1955, § 2(a).

$\S \S \S$ The Muslim Personal Law (Shariat) Application Act, 1937, § 2. 
Jews have their own personal law. The only common feature of all these different personal laws is that, they are prejudiced towards women and shows favoritism to men.

\section{Gender-Based Discrimination under Hindu Law}

\section{Marriage and Divorce Laws}

The ancient Hindu Law discriminated women in all respects. The marriage laws were not equal for men and women. The nature of Hindu marriage is described under the Vedas. According to Vedas a Hindu marriage is an indissoluble union till eternity. It is defined as a union of "bones with bones, flesh with flesh and skin with skin, the husband and wife become as if they were one person. ${ }^{* * *}$ Hindu marriage is a sanskara or a Sacrament. It is indissoluble in the sense, the woman cannot ask for another husband, even if he is cruel, drunkard, impotent, insane or whatsoever. It is eternal and continues for lives in the sense that she cannot take another husband even after his death. Husband and wife become one person in the sense she cannot have any individuality of her own. But the husband could enter into the sacramental fold of marriage any number of times because unlimited polygamy was permitted under Hindu law before enactment of the Hindu Marriage Act, 1955.

The Hindu Marriage Act, 1955 has removed these disparities to a large extent. It has made monogamy the rule for both men and women. Woman can dissolve her marriage and freely enter into another marriage according to law. The Hindu Marriage Act, 1955 has enumerated the grounds for divorce. Section 5 of the Hindu Marriage Act, 1955 lays down the conditions for a marriage. It says both the parties to the marriage should have the capacity to give

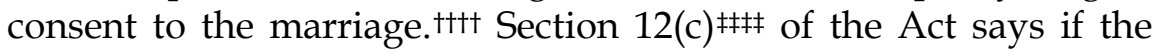
consent was obtained by force or fraud then the marriage is voidable. If the consent is not obtained at all then it will not affect

${ }^{* * * *} 2$ SHYAMA CHARAN SARKAR, VYAVASTHA CHANDRIKA 480 (1883).

ttt† The Hindu Marriage Act, 1955, § 5 .

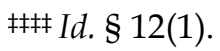


the validity of the marriage. This applies both to the husband and the wife. But practically, what happens in the male dominant society is that, only the consent of the boy is obtained, and consent of the girl is ignored. The boy may be much older to her, absolutely not suitable for her but without taking her consent the marriage takes place. However, on this ground the marriage cannot be dissolved. She has to bring it under the grounds for dissolution of marriage provided under the Hindu Marriage Act, 1955, otherwise dissolution of marriage is not possible. If the marriage was solemnized without her consent or against her wishes, she still continues to be in the marriage fearing society or because of parental pressure. But under Muslim law, if there is no free consent, then there is no marriage. If the marriage has taken place against his or her wishes, the marriage will be void.\$s\& This provision is not available to Hindu women. Though divorce is recognized under all the personal laws only a woman who has her own income or who has wealthy parents to support can opt for it. The laws relating to maintenance of a divorced woman and her children are not strong enough to give protection for her.

\section{Property Rights of Women}

There were different schools of Hindu law prior to codification. Under these schools of law only coparceners are the owners of the joint family property. Women could not be a coparcener and hence had no property rights. It was in 1937, the Hindu Women's Right to Property Act was passed. It conferred property rights to women. But it did not give her absolute right over the property. In 1956, The Hindu Succession Act was passed. It gave property rights to women. Mother, wife and daughter were made Class-I heirs. The concept of coparcenary that only a son can be a coparcener and daughter cannot be a coparcener did not change. Even after passing of the Hindu succession Act, 1956, women were not kept on par with their male counterparts. But the Hindu Succession (Amendment) Act, 2005 has made a drastic change. Now the daughter has the same rights in the coparcenary property as that of

§§§§ TAHIR MAHMOOD, THE MUSLIM LAW OF INDIA 50 (1980). 
a son. ${ }^{* * * *}$ But even after this amendment, there is every possibility that the women can be deprived of the property rights. Because in the male dominated society, it is believed that only sons are entitled to the property. The male coparcener who has the power to dispose of his property by executing a willttttt may dispose of the property in favor of his sons, to avoid the property going to his daughter. Without keeping a check on the testamentary capacity of Hindu male, the Hindu succession Amendment Act, 2005 may not serve its true purpose.

\section{Matrimonial Property}

It is an unwritten rule in the Indian society that taking care of the household and children is the duty of women. A man is able to earn money only with the support given by his wife. Only when she takes care of the household and children he is able to concentrate on economic growth. But this contribution of the wife is never taken into consideration. Whatever property is purchased by the couple, by their common effort, is generally purchased in the name of the husband. Then the property belongs only to the husband. If for some reason, the marriage breaks, then she has to ask her husband for maintenance. In India we don't have any law relating to matrimonial property as it exists in foreign legal systems, where the interests of the women are protected.

\section{Law of Adoption}

The Shastric Hindu Law of adoption differed from one school to another. But the Hindu Adoption and Maintenance Act, 1956 introduced uniformity in the law of adoption among Hindus. Under the Shastric Hindu Law, a Hindu woman was permitted to adopt a child only under rare circumstances. Her right to adopt a child was very limited. Though under the Hindu Adoption and Maintenance Act, 1956 the right of a woman to adopt a child is recognized, discrimination against woman continues. According to the Hindu Adoption and Maintenance Act, 1956, a married man

${ }^{* * * * * *}$ The Hindu Succession (Amendment) Act, 2005, § 6.

ttttt The Hindu Succession Act, 1956, § 6 . 


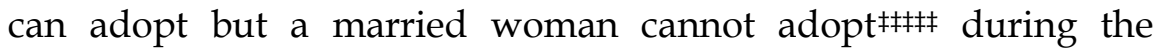
subsistence of the marriage. Now this disparity has been removed by the Personal Laws Amendment Act, 2010.\$ssss

\section{Gender-Based Discrimination under Muslim Law}

\section{Marriage and Divorce Laws}

A Muslim marriage called nikah is not a sacrament but a civil contract made for the purpose of procreation. Consent of the bride and the bridegroom is the basis of this contract. ${ }^{* * * * *}$ So, if the parties are adults, then their free consent is essential for a valid marriage and nobody else's consent is required. $\mathrm{ttttt}^{\mathrm{t}}$ If there is no free consent, then there is no marriage. In case of minor or person of unsound mind consent can be given by guardian. In such cases the minor on attaining majority can either ratify the marriage or repudiate the marriage. It is called option of puberty. So, a girl cannot be forced into marriage. Even if she is forced into it, it is not valid marriage. She can exercise the option of puberty and dissolve

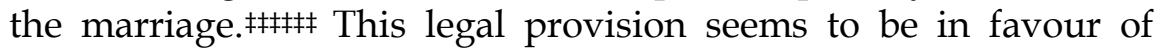
women giving her right to decide about her marriage. But she can exercise the option of puberty, only when she can support herself or where somebody is there to support her. Under Muslim Law, the law of maintenance of women after dissolution of marriage is not in favour of women. A Muslim divorced wife can get maintenance from her husband only during the period of idaat. $\$ \$ \& \S s \S$ After that, if she is not able to maintain her then her children, her parents, her other relatives who will inherit her property on her death has the liability to maintain her. If no one is in a position to maintain her,

\footnotetext{
执‡ The Hindu Adoption and Maintenance Act, 1956, § 8.

§§\$s The Personal Laws Amendment Act, 2010, § 8.

Amina v. Hassan Koya, (2003) 6 S.C.C. 93.

tttttt The Fatwai Alamgiri, I 405; The Hedaya, 95.

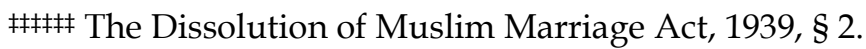

ss§s\&§ The Muslim Women (Protection of Rights on Divorce) Act, 1986, § 2(b).
} 
then the court may order the State Wakf Board to maintain her. Like other 'divorced wives' who are governed by other personal laws a Muslim divorced wife cannot get maintenance from her husband under the criminal Procedure Code. Only when she and her husband agree to be governed by the provisions of Criminal Procedure Code, 1973 relating to maintenance they can get relief under the Criminal Procedure Code, 1973. $\mathrm{ttttttt}^{\mathrm{tt}}$ Also under Muslim law unrestricted powers are given to the Muslim husband to dissolve the marriage. But, a Muslim woman has no such rights. She can dissolve her marriage only according to the provisions of Dissolution of Muslim Marriage Act, 1939. Hence the grounds available are limited and the same constraint follows. A Muslim woman can opt for divorce only when she can support herself or somebody is there to support her.

Under Muslim Law a Muslim husband is permitted to have four wives at a time. Quran says: 'Marry of the women, who seem good to you, two or three or four, if you fear that you cannot do justice to

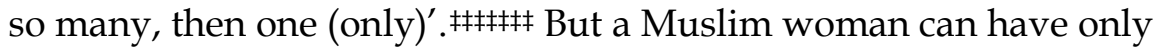
one husband. If she contracts a second marriage during the subsistence of the first marriage, then the second marriage is void. She can be punished for bigamy under the Indian Penal Code, 1860. A Muslim man can marry a Muslim girl, a Christian or a Jewish girl. But a Muslim girl can marry only a Muslim man. If she marries a Hindu, Jew or a Christian man, the marriage is void. $\$ s s \S s s \S$

\section{Property Rights of Muslim Women}

Till the passing of the Shariat Act, 1937 the Muslims in India were governed by customary laws which were highly unjust and were against women. After the Shariat Act, 1937 Muslims in India came to be governed in their personal matters, including property rights, by Muslim personal law. But this did not make any major changes

******* Id. $\S 4$.

t†ttt† $I d$. § 5 .

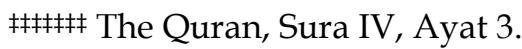

$\S \S \S \S \S \S \S$ AFAR A. A. FYZEE \& TAHIR MAHMOOD, MuHAMMEDAN LAW 99 (2008). 
in the property rights of women. Under Muslim law, men and women have equal right of inheritance. If a Muslim male dies, and his heirs include both male and female, both will inherit the property simultaneously. But a man's share of the inheritance is double that of a woman in the same degree of relationship to the deceased. The quantum of property inherited by a female heir is half of the property given to a male of equal status. It is a manifest sample of unequal treatment of women under Muslim law.

\section{Conclusion}

Women have been exploited for centuries. They have been denied just place in the society. Renowned poet Rabindranath Tagore has expressed his views on the plight of women as -

"O lord why have you not given women the right to conquer her destiny?

Why does she have to wait head bowed?

By the roadside, waiting with tired, patience, hoping for miracle in

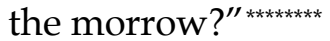

The women of this era want equal rights with men. It is only with the unification of personal laws in the form of a uniform civil code consisting of fair, just and non-discriminatory provisions that the women will enjoy their human rights in letter and spirit. The formulation of a uniform civil code would go a long way in improving the status of women in India.

Aruna Goel, Violence AND Protective MeAsures for WOMEN DEVELOPMENT AND EMPOWERMENT 78 (2004). 